\title{
Duchovní rozměr sociální pedagogiky Pohled očima studentů Cyrilometodějské teologické fakulty Univerzity Palackého v Olomouci Petra Potměšilová
}

\begin{abstract}
Abstrakt:
Studijní program Sociální pedagogika na Cyrilometodějské teologické fakultě má svá specifika. Při studiu je kladem dưraz na rozvoj hodnot, které jsou akcentovány v křestanské tradici. Toto specifikum je plně v souladu i s jedním z teoretických pilíru sociální pedagogiky (solidarita, pomoc druhým). Cílem výzkumu bylo zaměřit se na pohled studentů na potenciální význam duchovního přesahu studijního programu Sociální pedagogika. Hlavní výzkumnou metodou byl dotazník, který obsahoval deset otázek. Výsledky byly zpracovány pomocí programu IBM SPSS 21 a 23. Byla použita popisná statistika a pro ověřování hypotéz byl použit T-test pro dva nezávislé výběry, Analýza rozptylu (ANOVA), Kruskalův-Wallisův test a Pearsonův korelační koeficient. Výsledky prokázaly, že studenti vnímají pozitivně duchovní rozměr studijního programu Sociální pedagogika a že v tomto vnímání hraje roli i to, zda je víra pro ně osobně v životě důležitá a v kterém roce studia právě studují.
\end{abstract}

\section{Klíčová slova:}

sociální pedagogika, studijní program, duchovní rozměr, solidarita, víra

\section{1. Úvod}

Sociální pedagogika je jedním z oborů, který lze řadit mezi humanitně orientované obory a mezi obory, které jsou vymezovány jako pomáhající. Definovat sociální pedagogiku není až tak snadné, jak by se na první pohled zdálo. Kraus ${ }^{1}$ uvádí, že definice sociální pedagogiky se v průběhu historie měnila v souvislosti se změnou pojmu „sociální: od potřeby pomoci těm, kteři se dostali do složité životní situace, až po vztah k celé společnosti, tedy ve smyslu výchovy všech společenských kategorií pro život $\mathrm{v}$ dané společnosti. Tato dvě pojetí sociální pedagogiky se v České republice ustálila a odpovídá tomu i zaměření jednotlivých studijních programů.

Jednou z možností, kde lze v České republice studovat Sociální pedagogiku je Cyrilometodějská teologická fakulta Univerzity Palackého v Olomouci. V této souvislosti se často objevují otázky odborné veřejnosti po odlišnosti pojetí sociální pedagogiky na Cyrilometodějské teologické fakultě a legitimizaci tohoto oboru právě na teologické fakultě. Tyto otázky a výroky studentů, které

1 Bohuslav KRAUS, Základy sociální pedagogiky, Praha: Portál, 2008, s. 39. 
byly v průběhu let 2009-2019 náhodně zaznamenávány (viz text dále - kap. č. 4), vyústily v záměr uskutečnit výzkumné šetření s cílem hledání odpovědi na základní otázky, zda a jak se toto studium odlišuje od studijních programů na jiných vysokých školách v České republice, jestli a jak toto př́ípadné odlišení studenti vnímají.

\section{Teoretické ulkotvení}

Kořeny sociální pedagogiky lze hledat v Německu, kdy v roce 1844 Karl Mager poprvé používá pojem sociální pedagogika, a to v souvislosti s potřebou propojit výchovu a sociální realitu. ${ }^{2}$ Adolph Diesterweg pak pojem sociální pedagogika posouvá spíše do oblasti sociální politiky, a zdůrazňuje tak potřebu pomoci (jak materiální, tak výchovné) jedincům v sociální nouzi. ${ }^{3}$ Gottschalk ${ }^{4}$ uvádí, že do počátku 20. století se koncepce sociální pedagogiky v Německu dále rozvíjela. Do debaty nad koncepcí zasahovalo mnoho vlivů, jako byla např. morální filozofie, epistemologie či různé sociální teorie. V současné době je sociální pedagogika podle Sünkera a Braches-Chyrek ${ }^{5}$ chápana jako vědecký kontext, kde jedinec je schopen se na základě výchovného procesu vyvíjet tak, že může měnit svoji životní situaci. Noack ${ }^{6}$ následně uvádí, že sociální pedagogika je téměř shodná se sociální prací, ale na rozdíl od ní se kromě profesionální péče soustředuje i na výchovu. O specifickém vztahu sociální pedagogiky a sociální práce píše Öbrink Hobzová7 v knize Sociální pedagogika a její metody. $\mathrm{V}$ jistém smyslu se mohou tyto disciplíny zčásti překrývat, nebơ obě mohou napomoci změnit jedinci jeho životní situaci, avšak sociální pedagogika posouvá problémy, a tudíž i práci s jedincem, více do výchovných situací. Tím se od sociální práce liší.

Z Německa se sociální pedagogika postupně rozširíila i do dalších zemí. V České republice má sociální pedagogika svoji tradici od 19. století. Za zakladatele sociální pedagogiky autoři Kraus ${ }^{8}$ i Procházka9 shodně považují Adolfa Lindnera, který působil jako profesor pedagogiky na Univerzitě Karlově v Praze. Postupem času se sociální pedagogika v České republice etablovala jak v praktickém využití, tak jako vědní disciplína. Kraus ${ }^{10}$ shrnuje pět základních významových oblastí, které utvářejí rámec sociální pedagogiky: objekt výchovy (výchova je zaměřena na celé sociální skupiny, nikoliv na jednotlivce), formy a podmínky výchovy (mimoškolní instituce, lokální prostředí), cíle výchovy (společenské potřeby, spolupráce, altruismus...), metody výchovy (nepř́imé výchovné postupy), smysl sociální pomoci (solidarita s potřebnými). Zajímavou definici sociální pedagogiky uvádí Bakošová. ${ }^{11}$ Sociální pedagogiku vnímá jako životní pomoc, tedy jakousi komplexní péči o děti, mládež i dospělé v různých typech prostředí a přisuzuje jí čtyři základní cíle: ${ }^{12}$ objasňování vztahů výchovy a prostředí, výchovná intervence a právní nároky na výchovu,

2 Srov. Juha HÄMÄLÄINEN, Social Pedagogy as a Scientific Discipline - a Branch of Academic Studies and a Field of Professional Practice, EccoS Revista Científica 48/2019, s. 17-34.

3 Srov. Franz HAMBURGER, Sozialpädagogik in Deutschland. Eine Darstellung aus der Perspektive erziehungswissenschaftlicher Tradition, Journal of Contemporary Educational Studies 3/2014, s. 14-30.

4 Srov. Gerhard Michael GOTTSCHALK, Entstehung und Verwendung des Begriffs Sozialpädagogik. Extrapolation systematischer Kategorien als Beitrag für das Selbstverständnis heutiger Sozialpädagogik. Eichstätter Sozialpädagogische Arbeiten, Eichstätt: BPB-Verl., 2004.

5 Heinz SÜNKER - Rita BRACHES-CHYREK, Social pedagogy in Germany, in: The diversity of social pedagogy in Europe, ed. Jacob KORNBECK - Niels Rosendal JENSEN, Bremen: Europäischer Hochschulverlag, 2009, s. 18.

6 Winfried NOACK, Sozialpädagogik: ein Lehrbuch, Freiburg im Breisgau: Lambertus, 2011, s. 26.

7 Srov. Milena ÖBRINK HOBZOVÁ, Metody v disciplínách blízkých sociální pedagogice, in: Sociální pedagogika a její metody, Petra SOBKOVÁ a kol., Olomouc: UP, 2015, s. 25-28.

8 Srov. KRAUS, Základy..., s. 11.

9 Srov. Miroslav PROCHÁZKA, Sociální pedagogika, Praha: Grada, 2012, s. 54.

10 Srov. tamtéž, s. 40.

11 Srov. Zlatica BAKOŠOVÁ a kol., Sociálna pedagogika, Bratislava: Slovenské pedagogické nakladatelstvo, 2005 , s. 47.

12 Srov. tamtéž, s. 19. 
chápání výchovy jako pomoci všem věkovým kategoriím klientů a studium a intervence v oblasti odchylek sociálního chování.

V úvodu bylo zmíněno současné dvojí pojetí sociální pedagogiky v České republice. Kraus a Poláčková ${ }^{13}$ uvádějí širší pojetí sociální pedagogiky, tedy vytváření souladu mezi potřebami jedinců a společnosti, tj. přispívání $\mathrm{k}$ optimálnímu způsobu života $\mathrm{v}$ dané době a daných společenských podmínkách. Užší pojetí sociální pedagogiky pak charakterizuje např. Matoušek ${ }^{14}$, který podstatu sociální pedagogiky vidí v rozpoznávání sociálních činitelů ohrožujících vývoj člověka a v uplatňování postupů, jež vyvažují jejich nepříznivé působení. Rajský ${ }^{15}$ uvádí, že jádrem výchovy by právě měla být schopnost, která pomáhá osvobodit lidskou přirozenost od různých empirických determinant a zabezpečuje dosahování osobní a sociální plnosti. Tento všeobecný účel pedagogiky je v sociální pedagogice umocněn a je mu dána priorita. Podle Procházky ${ }^{16}$ stojí sociální pedagogika na dvou základních piliríích: na filozofickém myšlení, které se soustř̌eduje na výpovědi o vztahu společnosti a člověka, a na sociální práci jakožto péči, solidaritě a starosti o druhé.

At̂ už bude sociální pedagogika vnímána jako disciplína, jejíž cílovou skupinu tvoří jedinci v riziku, či jako disciplína, která se zabývá obecným vlivem prostředí na výchovu jedince, lze v obou pojetích najít společné body, a to především výše zmiňovanou pomoc, solidaritu či starost o druhé.

Co však řadí sociální pedagogiku mezi humanitní vědy? Foucault ${ }^{17}$ uvádí, že každá z humanitních věd vznikla u prŕležitosti nějakého problému, požadavku, překážky teoretického nebo praktického řádu. Dále pak uvádí, že vědy o člověku jsou postaveny na třech pilírích, a to na biologii, ekonomii a studiu řeči. $Z$ oblasti biologie se jedná o schopnosti nalézat průměrné normy přizpůsobení existenčním podmínkám, dále z hlediska ekonomie o pokus o uspokojení vlastních zájmů a $\mathrm{z}$ hlediska studia řeči o význam lidského chování. ${ }^{18} \mathrm{Na}$ základě propojení výše uvedeného lze konstatovat, že humanitní podstata sociální pedagogiky je výchovné působení na člověka ve smyslu pomoci a solidarity, tedy jakési dobročinnosti či prokazování dobra druhým. Pomoc, solidarita či prokazování dobra jsou těžko měřitelná jednání, ke kterým jsou jedinci vedeni nebo nevedeni výchovou, stavem společnosti, která ale zároveň významně souvisí s duchovní oblastí života. Př́kladem společenského vlivu na rozvoj solidarity může být vyhlášení světového dne sociální spravedlnosti, který v roce 2007 vyhlásila Organizace spojených národů (OSN). ${ }^{19}$ Cílem tohoto dne je upozornit na důležité otázky, jako je boj za odstranění chudoby, dodržování lidských práv a výchova $\mathrm{k}$ rovnosti a vzájemnému respektování. $\mathrm{V}$ souvislosti s prokazováním dobra je vhodné se zmínit o lásce, která bývá vnímána jako podstatná veličina $\mathrm{v}$ pomoci a dobročinnosti. Pelcová ${ }^{20}$, která se opírá o teorii Maxe Schelera, konstatuje, že láska nás činí vnímavými a otevřenými, nenávist nás uzavírá, zapouzdřuje a odsuzuje k izolaci, narcismu a individualismu. Autorka tak téma „pomoci“ posouvá dále a poukazuje na to, že láska je nejen podstatou vnímavosti a otevřenosti k druhým, ale že zpětně může přinášet dobré pocity jedinci. Šarníkováa ${ }^{1}$ chápe lásku v souladu s Maslowovou

13 Srov. Blahoslav KRAUS a kol., Člověk - prostředí - výchova: k otázkám sociální pedagogiky, Brno: Paido, 2001, s. 12.

14 Srov. Oldřich MATOUŠEK a kol., Metody a řizení sociální práce, Praha: Portál, 2003, s. 210.

15 Srov. () Andrej RAJSKÝ, What's Wrong in Modern Education? Maritain's Warning is Valid Today More than Ever, Caritas et Veritas 2/2018, s. 60. Dostupné na: http://www.caritasetveritas.cz/index.php?action=openfile\&pkey=279, citováno dne 23. 5. 2019.

16 Srov. PROCHÁZKA, Sociální..., s. 11.

17 Srov. Michael FOUCAULT, Slova a věci, Brno: Computer Press, a.s., 2007, s. 264.

18 Srov. tamtéž, s. 273.

19 (C) Organizace spojených národů. Dostupné na: https://www.osn.cz/events/event/svetovy-den-socialni-spravedlnosti-2016-02-20/, citováno dne 11. 5. 2019

20 @ Naděžda PELCOVÁ - Ilona SEMERÁDOVÁ, Fenomén výchovy a etika učitelského povolání, Praha: Karolinum Press, 2014. Dostupné na: http://search.ebscohost.com/login.aspx?direct=true\&db=nlebk\&AN=1107667\&lang=cs\&site=eds-live. Citováno dne: 10. 5. 2019, s. $84-85$.

21 Srov. Gabriela ŠARNíKOVÁ, Život v spoločenstve - láska či prosociálnost?, In: Edukacja. Działania społeczne. Rodzina, Wiesław WÓJCIK - Erika LALÍKOVÁ, Bielsko-Biała: Wydawnictwo Akademii Techniczno-Humanistycznej, 2008, s. 37-43. 
teorií jako potřebu a tvrdí, že když chybí dítěti láska, nechybí mu jenom potřeba dostávat i přijímat, ale také potřeba dávat. Tento rozměr patří v profesi sociálního pedagoga ke klíčovým.

V souvislosti $s$ duchovním rozměrem pomoci, prokazování dobra a projevováním lásky nelze opomenout Bibli. Ježíš nabádá k pomoci druhému: Jak chcete, aby lidé jednali s vámi, tak jednejte vy s nimi (L 6,31). Ježíš však dále pokračuje a dodává, že na tomto není nic zvláštního, že to, co je podstatou nezištné pomoci a dobrodiní, je ... milovat své nepřátele; činit dobře, půjčovat a nic nečekat zpět ... být milosrdní, jako je milosrdný Otec (L 6,35-36). V listě Ř́manům ( lze setkat s výrokem: Láska neudèlá bližnímu nic zlého. V celé Bibli je pak s láskou spojována Boží existence: Kdo nemiluje, nepoznal Boha, protože Bůh je láska (1J 4,8). Všechny uvedené pasáže z Bible tedy korespondují se základním posláním sociální pedagogiky - s pomocí, činěním dobra, doplňují ji však o duchovní hodnoty, tedy o nezištnost, lásku a ukotvenost v lásce $\mathrm{k}$ Bohu. Kromě Bible se lze obrátit i k papežským dokumentům ${ }^{22}$, které byly napsány od 19 . století a které se $s$ různou intenzitou věnují důstojnému postavení člověka ve světě. Sociální nauka církve ${ }^{23}$ se stala důležitou součástí učení církve a je stále akcentována i v dokumentech a promluvách současného papeže ${ }^{24}$ Konkrétním príkladem je sociální encyklika Deus caritas est ${ }^{25}$, kde je právě podrobně rozvedena souvislost lásky $\mathrm{k}$ Bohu a k bližnímu, tak jak bylo výše naznačeno.

\section{Studijní program Sociální pedagogika na Cyrilometodějské teologické fakulltě}

V České republice je možné studovat sociální pedagogiku na několika různých vysokých školách. I přes odlišnost pojetí jednotlivých studijních programů se pohybují ve výše uvedeném rozmezí sociální pedagogiky. V roce 2017 Asociace vzdělavatelů v oblasti sociální pedagogiky publikovala Standardy vzdělávání $\mathrm{v}$ oblasti sociální pedagogiky ${ }^{26}$. Tyto standardy obsahují základní tematické rámce studia, rámcový profil absolventa - jeho uplatnění a relevantní profese.

Studijní program Sociální pedagogika na Cyrilometodějské teologické fakultě (CMTF) je postaven na širším pojetí sociální pedagogiky a studijní plán odpovídá výše uvedeným standardům. $V$ profilu absolventa je však navíc uvedena zmínka, že vzhledem k zaměření Cyrilometodějské teologické fakulty bude kladen dưraz na rozvoj hodnot a principů akcentovaných $\mathrm{v}$ křestanské tradici a jejich využití ve výchovném procesu. ${ }^{27}$ Při tvorbě koncepce studijního programu byly vytyčeny dvě základní oblasti, které by měly obohacovat studijní plán a zohlednit výše uvedenou deklaraci. Prvním okruhem je začlenění specifických předmětů, které se zaměřují na vnímání hodnot a duchovní rozměr člověka, a dále obohacování všech předmětů o křestanský pohled na danou problematiku. Druhým okruhem je osobní př́íklad a svědectví akademických pracovníků.

$\mathrm{V}$ prŕípadě teoretického obohacení studijního plánu jsou zdůrazňovány křestanské kořeny kultury a jejich odpad na výchovu. Jako př́klad může posloužit Desatero Božích přikázání a jeho účinek nejen na právní systémy, ale především na morální cítění a následný vliv na výchovu. Zajímavý odkaz

22 Např. Rerum novarum (1892), Quadragesimo anno (1941), Mater et magistra (1961), Pacem in terris (1961), dokumenty 2. vat. koncilu jako Gaudium et spes (1965) nebo Dignitatis humanae (1965), sociální encykliky Jana Pavla II. nebo Caritas in veritate (2009) Benedikta XVI.

23 Podrobněji např. Kompendium sociální nauky církve, Kostelní Vydř́: Karmelitánské nakladatelství, 2008.

24 Laudato si (2015).

25 Deus caritas est, čl. 16-18.

26 C) Asociace vzdělavatelů v sociální pedagogice, Standardy vzdělávání v oblasti sociální pedagogiky. Dostupné na: http://asocped.cz/ folders-1305/, citováno dne 12.5. 2019.

27 Srov. Marcela FOJTÍKOVÁ ROUBALOVÁ, Duchovní rozměr sociálního pedagoga, in: Sociální pedagogika v teorii a praxi, Petra POTMĚŠILOVÁ a kol., Olomouc: Univerzita Palackého v Olomouci, 2013, s. 93-107. 
k zodpovědně pojaté výchově lze nalézt v Novém zákoně: Přísná výchova se ovšem $v$ tu chvíli nikdy

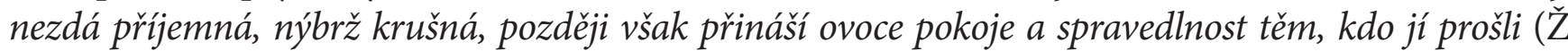
12,11). Jiným př́kladem, který souvisí s křestanskými kořeny a hodnotami, je seznamování studentů s důležitými rituály a svátky v životě člověka a s jejich křestanským versus světským významem. Do kontrastu je tak např́klad dáván význam křtu a význam vítání občánků. V obou př́ípadech se jedná o jakési přivítání do společnosti, $\mathrm{v}$ případě křtu je zde jasný duchovní podtext: $\mathrm{V}$ Janově evangeliu $(15,1-6)$ je podobenství o vinaři, kde lze spatřovat význam křtu - tj. jedinec se stává součástí Ježíšova těla. Křest lze tedy vnímat tak, že v něm zajisté nejde o odstranění tělesné špíny, nýbrž o dobré svědomí, k němuž se pred Bohem zavazujeme (1P 3,21). Člověk se křtem nestává jen pasivní součástí společnosti, nýbrž dostává možnost podílet se na Dobru. Dalším příkladem obohacení může být etická výchova, v níž je dáván důraz na osobnost mravně vyzrálého člověka, který je zaměřen prosociálně, tedy který se zaměřuje na pomoc jiným osobám či na jejich prospěch. Za duchovní přesah lze považovat pak to, že hlavním motivem pomoci je vnitřní potřeba člověka, nikoliv touha po odměně, což koresponduje s výše uvedenou pasáží z Bible (L 7,35-36) či s knihou Př́sloví (Př 21,21): Kdo jde za spravedlností a milosrdenstvím, najde život, spravedlnost a slávu. Druhou oblastí je pak osobní př́iklad a duchovní nastavení ${ }^{28}$ akademických pracovníků. Roubalová ${ }^{29}$ uvádí, že osobní duchovní nastavení hraje v procesu vzdělávání a formování studentů pro budoucí povolání nezanedbatelnou roli. Šarníková30 dodává, že duchovní rozměr člověka je jedním ze znaků lidské transcendence a kromě rodičů je to právě pedagog, který svým prríkladem probouzí a rozvíjí tento lidský rozměr i u svých svěřenců od předškolního věku po adolescenci. Chadima a kol. ${ }^{31}$ charakterizují tradiční křest̉anskou výchovu jako synergii tří základních faktorů: metapříběh Ježíše Krista, garance církve a přítomnost rodiny. Současně však připouštějí, že v dnešní době, době postmoderní, to není již tak časté a běžné.

V souvislosti s řešenou problematikou lze s výše uvedeným konstatováním vysledovat paralelu, která může tvořit rámec duchovního rozměru studijního programu: využití př́kladu Ježíše Krista a přítomnost vychovatelů - pedagogů, kteří budou schopni garantovat toto předávání. Hlavní otázkou, a tedy i podnětem pro realizování výzkumného šetření je, zda se podařilo nastavit duchovní přesah studijního oboru Sociální pedagogika, jak je tento přesah vnímán studenty a - pokud je př́tomen - jestli lze vysledovat jeho reálný dopad na studenty.

\section{Výzkum}

Výzkum byl realizován v rámci grantu IGA_CMTF_2019_006. Pro výzkum byla zvolena kvantitativní metodologie. Jako výzkumný nástroj byl použit dotazník s deseti položkami, který byl vytvořen autorem tohoto textu a respondentům byl distribuován v tištěné podobě.

\section{Cíl výzkumu, teoretická východiska a hypotézy}

Cílem výzkumu bylo zjistit, zda si studenti uvědomují křestanský rozměr oboru Sociální pedagogika na CMTF a zda je tento rozměr pro ně přínosem.

28 V př́padě akademických pracovníků CMTF je duchovní nastavení vnímáno ve smyslu křestanského rozměru.

29 Srov. Martina ORLOVSKÁ - Marcela ROUBALOVÁ, Učitelé a hodnoty - životní postoj učitele a předávání hodnot, in: Mládež a hodnoty 2010: Výchova k hodnotám v kontextu pluralitní a multikulturní společnosti, Jiří POSPÍŠIL - Marcela ROUBALOVÁ, Olomouc: Hanex, 2010, s. 185-193.

30 Srov. Gabriela ŠARNÍKOVÁ, Budú cnosti v budúcnosti? O výchove $k$ cnostiam, Ružomberok: Verbum, 2011, s. 78-81, 171-176; srov. Gabriela ŠARNÍKOVÁ, Spiritualita dietata ako súčast' hladania pravdy o sebe a o svete, Predškolská výchova 4/2019, s. 33-36.

31 Srov. Martin CHADIMA a kol., Mezigenerační přenos základních křestanských hodnot v kontextu sekulární společnosti, Hradec Králové: Gaudeamus, 2015, s. $84-85$. 
Teoretická východiska výzkumu vznikla na základě údajů uvedených v kap. 2 a 3 :

1. Pojetí sociální pedagogiky ve smyslu pomoci, konání dobra.

2. Konání dobra pro vnitřní uspokojení a v souladu s křestanskou tradicí.

Na základě teoretických východisek a cíle výzkumu byly stanoveny dvě výzkumné otázky:

V1: Vnímají studenti Sociální pedagogiky na CMTF křestanský rozměr studia?

V2: Je křestanský rozměr studia prijímán studenty pozitivně?

Při stanovování hypotéz se nevycházelo pouze z uvedených výzkumných otázek, ale i z předpokladu, že student, který si vybral studium na CMTF, počítá s tím, že studium má svá určitá specifika. Na základě těchto faktů pak byly stanoveny hypotézy:

H1: Mezi vírou studentů a pozitivním přijímáním křestanského rozměru studia není statisticky významná souvislost.

H2: Mezi vírou studentů a uvědomováním si dopadu křestanského rozměru studia není statisticky významná souvislost.

H3: Mezi rokem studia a uvědomováním si křestanského rozměru studia není statisticky významná souvislost.

\section{Výzkumný soubor}

Výzkumný soubor tvořili studenti oboru Sociální pedagogika na CMTF, kteří byli v akademickém roce 2018/2019 zapsáni ke studiu. Jednalo se tedy o záměrný výběr, kdy respondent musel splňovat výše uvedené kritérium. V akademickém roce 2018/2019 bylo dle Studijní agendy (STAG) zapsáno ve všech ročnících i typech studia celkem 138 studentů. Celkem se vrátilo 122 vyplněných dotazníků, což je necelých $89 \%$.

Do výzkumu byly zahrnuty všechny dotazníky, i když nebyly vyplněny ve všech položkách. Z celkového počtu $\mathrm{N}=122$ respondentů bylo $113(97 \%)$ žen a 9 (7\%) mužů. Věkové rozložení respondentů se pohybovalo od 19 do 52 let. Průměrný věk respondentů byl 28 let a nejvíce respondentů bylo ve věku 21 let (12\%).

\section{Metody analýzy dat}

Jak již bylo výše uvedeno, hlavní metodou sběru dat bylo dotazníkové šetření. Data byla přepsána do tabulky v programu Microsoft Excel a pro statistické zpracování byl použit program IBM SPSS $23^{32}$. Jako první byla provedena popisná statistika jednotlivých položek. Pro ověření platnosti hypotéz byl použit T-test pro dva nezávislé výběry, Analýza rozptylu (ANOVA), Kruskalův-Wallisův test a Pearsonův korelační koeficient.

\section{Výsledky}

První čtyři otázky v dotazníku se týkaly demografických údajů. Zbývající otázky pak byly zaměřeny na zjištování údajů o vztahu studentů ke studiu.

Na úvod byli respondenti dotazováni na důvod výběru studia Sociální pedagogiky na CMTF UP. Studenti mohli vybrat více možností, proto celkový počet odpovědí neodpovídá počtu respondentů. 


\begin{tabular}{|l|l|l|}
\hline Důvod výběru studia & Četnost & $\mathbf{\%}$ \\
\hline Studium na CMTF jsem si vybral/a, protože je to teologická fakulta & 22 & 13 \\
\hline Studium na CMTF jsem si vybral/a na základě doporučení & 31 & 19 \\
\hline Studium na CMTF jsem si vybral/a kvo̊li nabízenému oboru & 97 & 59 \\
\hline Studium na CMTF jsem si vybral/a z jiného důvodu & 14 & 9 \\
\hline CELKEM & $\mathbf{1 6 4}$ & $\mathbf{1 0 0}$ \\
\hline
\end{tabular}

Tab. ̌́. 1 Dưvod výběru studia

Z tabulky č. 1 je patrné, že 59 \% odpovědí se týkalo přímo daného oboru. 22 respondentů uvedlo jako důvod to, že byl obor nabízen na CMTF.

Z celkového počtu 122 respondentů $57 \%$ uvedlo, že pro jejich život není víra důležitá, zbývajících 43 \% naopak uvedlo, že víru vnímají jako důležitou součást svého života. Celkem 10 respondentů mělo potřebu vyjasnit, co rozumí pod pojmem víra: nadpřirozený přesah, nepraktikující víra, duchovní síly v prrírodě; a dále upřesnit, o jaký typ křestanství se jedná.

Dále bylo zjištováno, zda počet předmětů, v nichž se vyučující dotýkají duchovních věcí, je pro studenty vyhovující, či nikoli, a zda jim vůbec tyto předměty vyhovují.

\begin{tabular}{|l|l|l|}
\hline Položka & Četnost & $\%$ \\
\hline naprosto vyhovuje & 39 & 32 \\
\hline spíše vyhovuje & 17 & 14 \\
\hline vyhovuje & 55 & 45 \\
\hline spíše nevyhovuje & 11 & 9 \\
\hline vůbec nevyhovuje & 0 & 0 \\
\hline (prázdné) & 0 & 0 \\
\hline CELKEM & $\mathbf{1 2 2}$ & $\mathbf{1 0 0}$ \\
\hline
\end{tabular}

Tab. ̌́. 2 Počet předmětů

\begin{tabular}{|l|l|l|}
\hline Položka & Četnost & $\%$ \\
\hline naprosto vyhovuje & 32 & 26 \\
\hline spíše vyhovuje & 20 & 16 \\
\hline vyhovuje & 57 & 47 \\
\hline spíše nevyhovuje & 11 & 9 \\
\hline vůbec nevyhovuje & 1 & 1 \\
\hline (prázdné) & 0 & 1 \\
\hline CELKEM & $\mathbf{1 2 1}$ & $\mathbf{1 0 0}$ \\
\hline
\end{tabular}

Tab č. 3 Přijetí predmětů 
Z obou výše uvedených tabulek je patrné, že téměř $50 \%$ respondentů uvedlo, že jim tento typ předmětů vyhovuje a také, že jim vyhovuje jejich počet, resp. téměř $90 \%$ respondentů vyjadřuje souhlas nejen $s$ předměty, ale i $s$ jejich počtem. Pro zjištění korelací mezi těmito dvěma odpověd’mi byl použit Spearmanův korelační koeficient. Na základě vypočítané hodnoty $(r=0,65$, $\mathrm{p}<0,01)$ lze konstatovat, že respondenti odpovídali v obou otázkách souhlasně.

Následně byl zjištován dopad předmětů s duchovní tématikou na osobní, studijní i pracovní život. V grafu č. 1 jsou uvedeny výsledky jednotlivých škál ${ }^{33}$ tak, aby bylo možné porovnat odpovědi respondentů $\mathrm{v}$ jednotlivých oblastech.

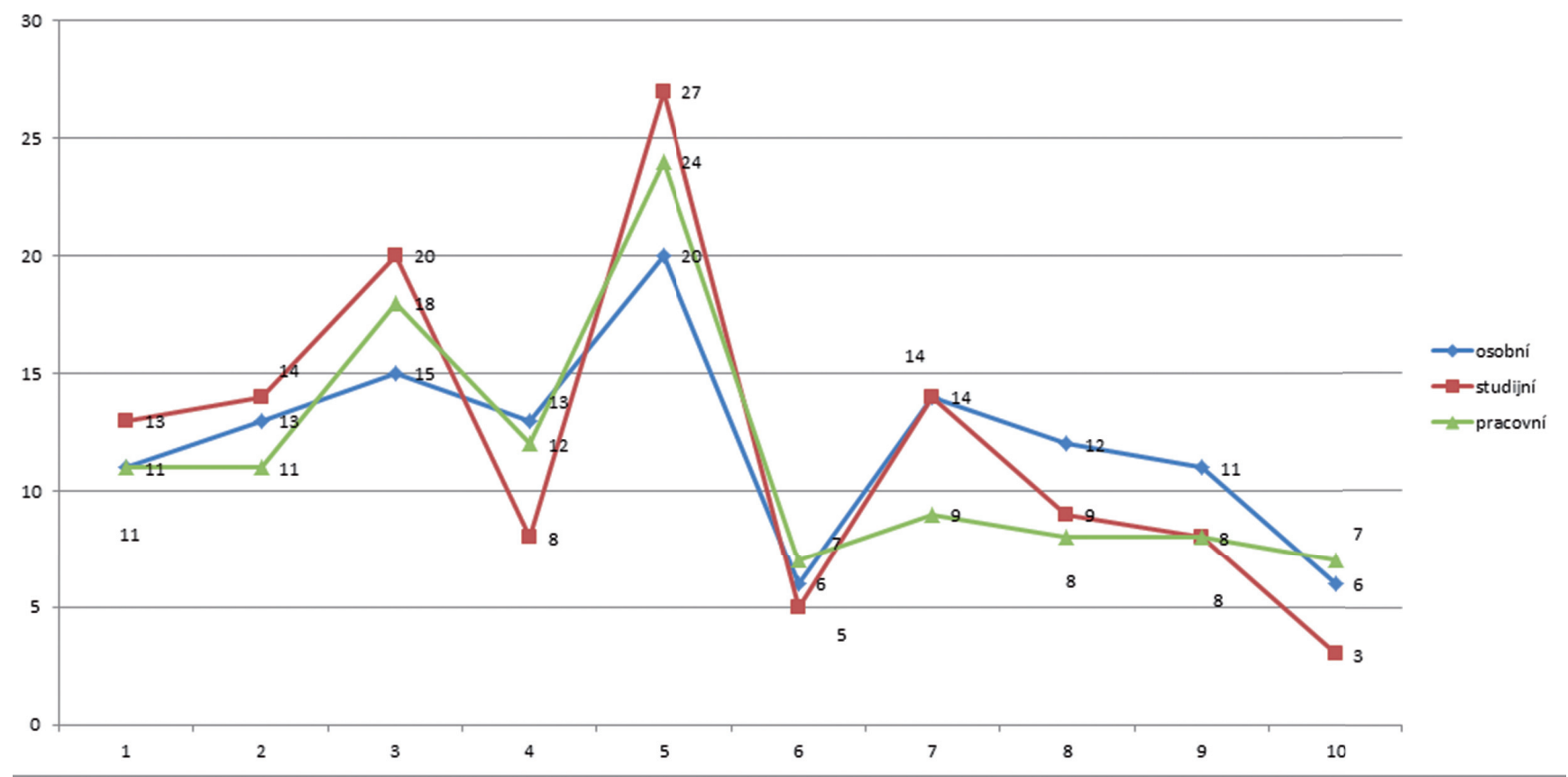

Graf ̌̌. 1 Dopad předmětů

Vztah mezi těmito třemi dopady byl zjištován opět pomocí Spearmanova korelačního koeficientu. Vypočítané hodnoty prokazují vztah mezi osobním a studijním významem $(\mathrm{r}=0,61, \mathrm{p}<0,01)$, osobním a pracovním významem $(\mathrm{r}=0,47, \mathrm{p}<0,01)$ a také mezi studijním a pracovním významem $(\mathrm{r}=0,52, \mathrm{p}<0,01)$. Z těchto údajů vyplývá, že respondenti odpovídali ve všech třech otázkách shodně; pokud tedy vnímali význam studia v jedné oblasti, vnímali jej i v těch dalších a opačně.

Dalším specifikem studia Sociální pedagogiky na CMTF UP je to, že se studenti setkávají se skutečností, že členové akademického sboru se netají svou vírou a snaží se svým svědectvím dávat studentům př́klad. Kromě toho část akademického sboru jsou kněží či řádové sestry (zasvěcené osoby), a studenti se tak ve výuce s nimi pravidelně setkávají. V následujícím grafu (graf č. 2) jsou uvedeny údaje (víra vyučujících $\mathrm{M}=3,22, \mathrm{SD}=1,75, \mathrm{MOD}=5, \mathrm{MED}=3$; př́tomnost zasvěcených osob $\mathrm{M}=3,24, \mathrm{SD}=2,07, \mathrm{MOD}=1, \mathrm{MED}=3$ ), z nichž lze pozorovat, že obě specifika jsou studenty přijímána spíše pozitivně:

33 Míru souhlasu s danou položkou respondenti vyjadřovali na škále 1-10, kdy 1 znamenalo naprostý souhlas a 10 naprostý nesouhlas (platí pro graf č. 1 a 2). 


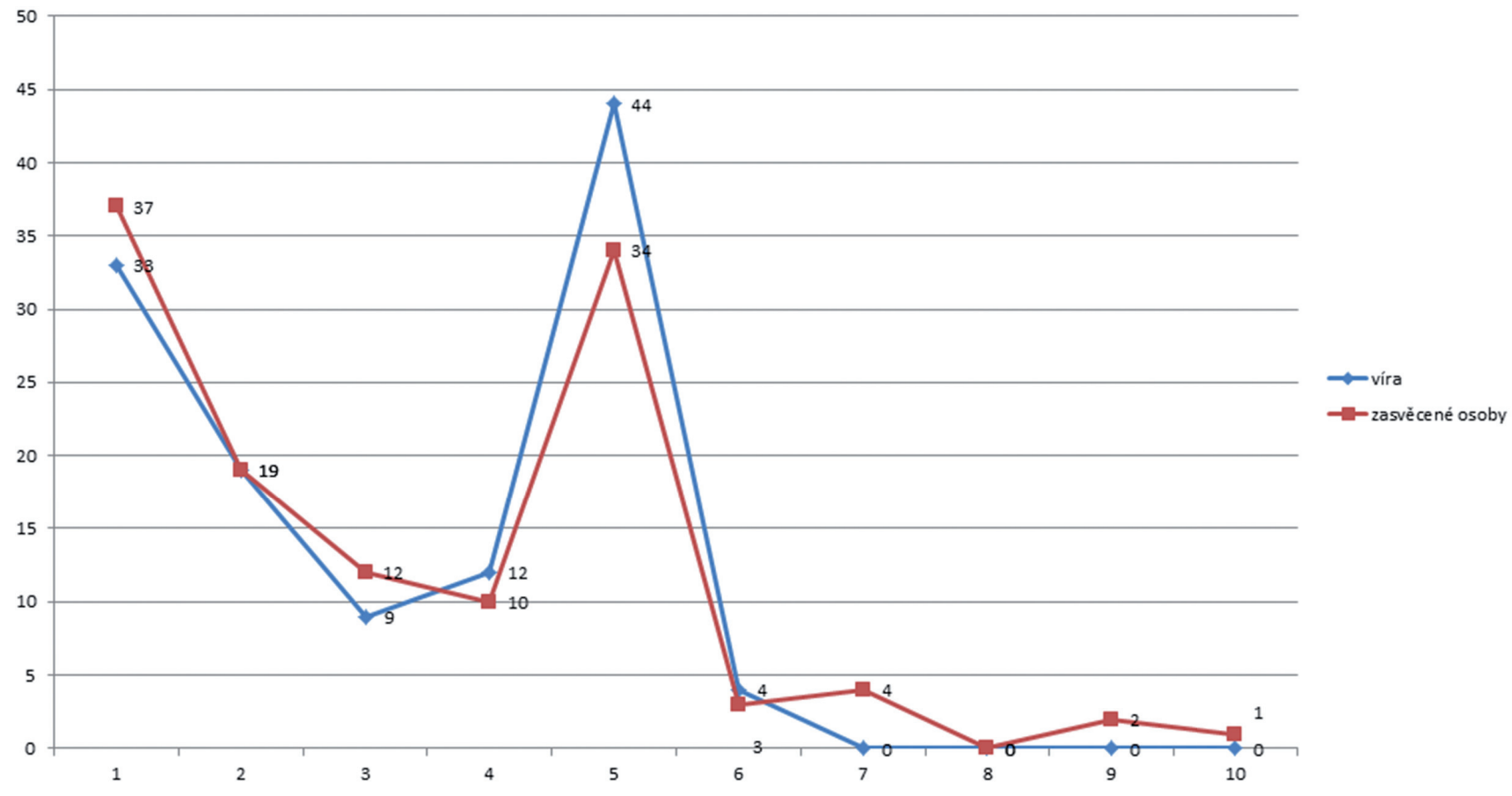

Graf č. 2 Vliv víry a zasvěcených osob

V odpovědích na otevřené otázky se v souvislosti s touto problematikou objevovaly výroky jako lidskost, osobní prístup, snaha pomoci... osobní přístup, větši ochota pomoci při řešení problémů... pozitivní prístup vyučujících.

\section{Ověřování platnosti hypotéz}

H1: Mezi vírou studentů a pozitivním přijímáním křestanského rozměru studia není statisticky významná souvislost.

Pro ověřování této hypotézy byly porovnávány odpovědi, v nichž se studenti vyjadřovali k tomu, zda jim vyhovuje počet předmětů a samotné předměty, v nichž se učitelé dotýkají duchovního rozměru. Nejprve byly vypočítány střední hodnoty, dále pak bylo přistoupeno k ověřování hypotézy pomocí T-testu pro dva nezávislé výběry. Z tabulky č. 4 lze získat přehled o tom, jaká byla průměrná odpověd’ na dané otázky podle toho, zda je či není víra v životě studentů důležitá:

\begin{tabular}{|l|l|l|l|l|}
\hline & Víra & Četnost & Průměr & Směrodatná odchylka \\
\hline Počet & ANO & 67 & 2,03 & 0,97 \\
\hline & NE & 51 & 2,67 & 0,97 \\
\hline Předměty & ANO & 66 & 2,03 & 0,98 \\
\hline & NE & 51 & 2,86 & 0,85 \\
\hline
\end{tabular}

Tab. ̌́. 4 


\begin{tabular}{|l|l|l|}
\hline T-test pro dva nezávislé výběry & Počet & Předměty \\
\hline F & 1,52 & 9,60 \\
\hline Signifikance & 0,221 & 0,002 \\
\hline $\mathrm{t}$ & $-3,53$ & $-4,84$ \\
\hline df & 116 & 115 \\
\hline Signifikance & 0,001 & 0,000 \\
\hline Rozdíl průměrů & $-0,64$ & $-0,83$ \\
\hline Standardní chyba rozdílu & 0,18 & 0,17 \\
\hline
\end{tabular}

Tab. ̌́. 5

Z vypočtených údajů z obou tabulek (Tab. č. 4 a 5) vyplývá, že je možné zamítnout nulovou hypotézu $(\mathrm{p}=0,001$, resp. 0,000 je tedy $<0,01)$ a konstatovat, že je statisticky významná souvislost mezi vírou a tím, zda studenti pozitivně vnímají křestanský rozměr studia.

H2: Mezi vírou studentů a uvědomováním si křestanského rozměru studia není statisticky významná souvislost.

Pro ověřování této hypotézy byly pomocí T-testu pro dva nezávislé výběry porovnávány odpovědi, v nichž se studenti vyjadřovali k tomu, zda vnímají význam předmětů s duchovním rozměrem v osobní, studijní a pracovní oblasti. Z tabulky č. 6 lze získat přehled o tom, jaká byla průměrná odpověd' na dané otázky podle toho, jestli je či není víra v životě studentů důležitá.

\begin{tabular}{|l|l|l|l|l|}
\hline & Víra & Četnost & Průměr & Směrodatná odchylka \\
\hline \multirow{2}{*}{$\begin{array}{l}\text { Význam } \\
\text { osobní }\end{array}$} & ANO & 66 & 3,82 & 2,20 \\
\cline { 2 - 5 } & NE & 51 & 6,81 & 2,30 \\
\hline \multirow{2}{*}{$\begin{array}{l}\text { Význam } \\
\text { studijní }\end{array}$} & ANO & 67 & 3,85 & 2,18 \\
\cline { 2 - 5 } & NE & 50 & 5,82 & 2,52 \\
\hline \multirow{2}{*}{$\begin{array}{l}\text { Význam } \\
\text { pracovní }\end{array}$} & ANO & 62 & 4,55 & 2,53 \\
\cline { 2 - 5 } & NE & 49 & 5,29 & 2,73 \\
\hline
\end{tabular}

Tab. ̌́. 6

\begin{tabular}{|l|l|l|l|}
\hline T-test pro dva nezávislé výběry & Význam osobní & Význam studijní & Význam pracovní \\
\hline F & 0,47 & 1,61 & 0,09 \\
\hline Signifikance & 0,49 & 0,21 & 0,77 \\
\hline t & $-7,15$ & $-4,53$ & $-1,47$ \\
\hline df & 115 & 115 & 109 \\
\hline Signifikance & 0,000 & 0,000 & 0,144 \\
\hline
\end{tabular}




\begin{tabular}{|l|l|l|l|}
\hline Rozdíl průměrů & $-2,99$ & $-1,99$ & $-0,74$ \\
\hline Standardní chyba rozdílu & 0,42 & 0,44 & 0,50 \\
\hline
\end{tabular}

Tab. ̌́. 7

Z vypočtených údajů z obou tabulek (Tab. č. 6 a 7) lze říci, že je možné ve dvou případech (osobní /p =0,000/ a studijní /p =0,000/ význam) zamítnout nulovou hypotézu a lze tedy konstatovat, že je statisticky významná souvislost mezi vírou a tím, zda si studenti uvědomují křestanský rozměr studia ve vztahu s osobním a studijním významem. V př́padě pracovního významu není možné zamítnout nulovou hypotézu ( $\mathrm{p}=0,144)$, tedy mezi vírou a uvědomováním si dopadu k pracovnímu uplatnění neexistuje statisticky významný rozdíl.

H3: Mezi rokem studia a uvědomováním si křestanského rozměru studia není statisticky významná souvislost.

Pro ověřování hypotézy byly s rokem studia porovnávány odpovědi na otázku po významu studia pro osobní, studijní i pracovní život. Pro testování hypotézy byla použita analýza rozptylu (ANOVA) a Kruskalův-Wallisův test.

\begin{tabular}{|l|l|l|l|l|l|l|}
\hline \multicolumn{2}{|c|}{} & Součet čtverců & df & $\begin{array}{l}\text { Průměrné } \\
\text { čtverce }\end{array}$ & F & Signifikance \\
\hline \multirow{2}{*}{$\begin{array}{l}\text { Význam } \\
\text { osobní }\end{array}$} & Mezi skupinami & 57.50 & 4 & 14.37 & 2.08 & 0.09 \\
\cline { 2 - 7 } & Uvnitř skupin & 801.83 & 116 & 6.91 & & \\
\cline { 2 - 7 } & Celkem & 859.32 & 120 & & & \\
\hline \multirow{2}{*}{$\begin{array}{l}\text { Význam } \\
\text { studijní }\end{array}$} & Mezi skupinami & 33.14 & 4 & 8.29 & 1.33 & 0.27 \\
\cline { 2 - 8 } & Uvnitř skupin & 723.73 & 116 & 6.24 & & \\
\cline { 2 - 7 } & Celkem & 756.88 & 120 & & & \\
\hline \multirow{2}{*}{$\begin{array}{l}\text { Význam } \\
\text { pracovní }\end{array}$} & Mezi skupinami & 66.81 & 4 & 16.70 & 2.60 & 0.04 \\
\cline { 2 - 8 } & Uvnitř skupin & 709.48 & 110 & 6.45 & & \\
\cline { 2 - 8 } & Celkem & 776.30 & 114 & & & \\
\hline
\end{tabular}

Tab. ̌́. 8 Analýza rozptylu

\begin{tabular}{|l|l|l|l|}
\hline & Význam osobní & Význam studijní & Význam pracovní \\
\hline Chí-kvadrát $\left(\mathrm{X}^{2}\right)$ & 7.85 & 4.73 & 9.38 \\
\hline df & 4 & 4 & 4 \\
\hline Signifikance & 0.10 & 0.32 & 0.05 \\
\hline
\end{tabular}

Tab. č. 9 Kruskali̊v-Wallisưv test

Z výsledků, které jsou uvedeny v Tab. č. 8 a 9, je patrné, že nelze zamítnout nulovou hypotézu ve vztahu k osobnímu a studijnímu významu. V prrípadě pracovního významu se prokázala statisticky 
významná souvislost s rokem studia na hladině významnosti $0,05(\mathrm{p}=0,04$, resp. 0,05$)$. Tedy mezi rokem studia a uvědomováním si křestanského rozměru studia $\mathrm{v}$ osobní a studijní rovině není statisticky významná souvislost, v rovině pracovní však ano.

Pro podrobnější zjištění vztahu mezi rokem studia a vlivem duchovního rozměru studia na pracovní oblast byl použit Pearsonův korelační koeficient (Tab. č. 10).

\begin{tabular}{|l|l|l|}
\hline & & Rok studia \\
\hline \multirow{3}{*}{ Význam pracovní } & Pearsonův korelační koeficient & $-0,29$ \\
\cline { 2 - 3 } & Signifikance & 0,002 \\
\cline { 2 - 3 } & $\mathrm{N}$ & 115 \\
\hline
\end{tabular}

Tab. ̌́. 10 Korelace roku studia a pracovního významu

Z údajů ve výše uvedené tabulce lze zjistit, že na hladině významnosti $0,01(\mathrm{p}=0,002)$ lze prokázat korelace mezi rokem studia a dopadem duchovního rozměru studia na pracovní uplatnění. Hodnota korelace naznačuje, že s vyšším ročníkem studia vzrůstá u studentů jeho pozitivní dopad.

\section{Diskuse}

Cílem výzkumu bylo zjistit pohled studentů na potenciální duchovní rozměr studijního programu Sociální pedagogika na CMTF UP. Z celkového počtu 122 respondentů necelá polovina uvedla, že je pro jejich život víra důležitá. Sak ${ }^{34}$ ve svých výzkumech prezentuje žebříček hodnot mladých lidí ve věku 19-30 let. Z 23 položek je dle něj Bůh na 22. místě. Dále pak uvádí, že v roce 2001 se k víře hlásilo cca 32 \% jedinců. Prudký ${ }^{35}$ uvádí, že orientace směřující k víre se u jedinců výrazně proměnila $\mathrm{v}$ souvislosti se změnou režimu v roce 1989. Tento fenomén dokonce nazývá termínem „Bůh po komunismu“ a uvádí, že v současné době36 je přesvědčených věřících až $15 \%$. Předkládaný výzkum ukazuje vyšší procento věřících lidí, což však může být způsobeno prostředím teologické fakulty, které přece jen více přitahuje věřící jedince.

Baštecká a Goldmann ${ }^{37}$ citují Vymětala, který mezi salutogenetické prvky řadí kromě smysluplnosti, srozumitelnosti a zvládání právě i víru. Jedná se o prvky, které jsou v životě jedince důležité a plní ochrannou roli. Neubauer upozorňuje na krizi křestanství a duchovních tradic. ${ }^{38} \mathrm{~V}$ této souvislosti následně uvádí, že duchovní cesta patří k všeobecné lidské potřebě a je zásadně neoddělitelná od lidské přirozenosti. Halík ${ }^{39}$ náboženskost pokládá za přirozenou dimenzi člověka a společnosti, podobně jako smysl pro krásu, pro humor či pro veřejný život.

Téměř 90 \% všech respondentů uvedlo, že jim vyhovuje jak počet předmětů, tak i jejich zaměření. I přesto se však ukázalo, že respondenti, kteří považují víru pro svůj život za důležitou, vnímají význam i počet předmětů s duchovní tématikou pozitivněji. Respondenti hodnotí pozitivně i chování a jednání akademických pracovníků.

34 Srov. Petr SAK - Karolína SAKOVÁ, Mládež na křižovatce, Praha: Svoboda Servis, 2004, s. 11 a s. 35.

35 Srov. Libor PRUDKÝ a kol, Inventura hodnot, Praha: Academie, 2009, s. 337.

36 Rok výzkumu 2001.

37 Srov. Bohumila BAŠTECKÁ - Petr GOLDMANN, Základy klinické psychologie, Praha: Grada, 2001, s. 293.

38 Srov. Zdeněk NEUBAUER, Smysl a duch, in: A nahoře nic..., Odilo ŠTAMPACH, Praha: Portál, 2000, s. 143.

39 Srov. Tomáš HALÍK, Co je bez chvění, není pevné, Praha: Nakladatelství lidové noviny, 2002, s. 28. 
Při vyhodnocování odpovědí na otázky, které se zabývaly možným dopadem křestanského rozměru studia na osobní, studijní a pracovní život, se prokázalo, že tyto odpovědi spolu korelují. Lze tedy říci, že respondenti odpovídali shodně na všechny tři otázky. Průměrné hodnoty odpovědí na jednotlivé vlivy: osobní $(\mathrm{M}=5,15, \mathrm{SD}=2,68, \mathrm{MOD}=5, \mathrm{MED}=5)$, studijní $(\mathrm{M}=4,71$, $\mathrm{SD}=2,51, \mathrm{MOD}=5, \mathrm{MED}=5)$ a pracovní život $(\mathrm{M}=4,92, \mathrm{SD}=2,61, \mathrm{MOD}=5, \mathrm{MED}=5)$ ukazují, že respondenti volili svoje odpovědi převážně ve středu škály. Kumulativní procenta dále ukazují, že v oblasti osobního vlivu volilo na škále 1-10 59,5\% respondentů odpovědi mezi 1-5, v oblasti studijního 67,8 \% a v oblasti pracovního to bylo $66,1 \%$ respondentů. Z toho tedy vyplývá, že více než polovina respondentů připouští vliv křest’anského rozměru studia. V souvislosti s vírou byla zaznamenána korelace s pozitivním dopadem na jejich osobní i studijní život. Na tomto místě je však nutné říci, že se primárně jedná o subjektivní sdělení respondentů, tedy spíše o pocit, že je studium ovlivnilo. Kromě současných studentů byl modifikovaný dotazník rozeslán i absolventům. Z celkového počtu 600 se vrátilo pouze $16 \%$ dotazníků a všechny odpovědi byly výrazně pozitivní: ... studium na „naší teologické fakultě byla nejlepší životní volba a skvělá zkušenost ... už při prijímacím řizení na mě „cosi dýchlo“ a já si tehdy př́la, abych se na tuto fakultu dostala ... poznala jsem zde skvělé lidi, ke kterým mám stále hodně blízko ... teologická fakulta - pro mne jediná možná volba! ... dali jste mi hodně do osobního i profesního života. Vzhledem k tomu, že nelze data z dotazníků považovat za objektivní, nebyla do výzkumného šetření zahrnuta.

Další položená otázka se týkala toho, zda vnímání duchovního rozměru studia se vyvíjí s rokem studia respondentů. V této souvislosti bývají zaznamenány výroky typu ${ }^{40}$.... postupem zjištuji, že je to vlastně normální a př́jemné prostředí, ... věřící člověk je docela normální a fajn..., ... jo, není to žádná sekta... Výzkum prokázal pouze souvislost s rokem studia v oblasti pracovní. Lze tedy říci, že se u studentů projevoval statisticky významný vývoj ve vnímání duchovního rozměru studia v souvislosti s pracovním uplatněním. Na základě všech uvedených výsledků lze tedy konstatovat, že v průběhu studia si studenti stále intenzivněji uvědomují pozitivní vliv duchovního rozměru studia ve vztahu k pracovnímu uplatnění.

\section{Limity studie}

Za základní limit studie lze považovat fakt, že objektem měření se zde stávají veličiny, které jsou obtížně měřitelné. Výzkumné šetření tak vychází ze vzájemné důvěry mezi respondenty a výzkumníkem. Respondenti sdělují své subjektivní pocity, které nelze objektivně potvrdit. Za další limit studie lze považovat osobu výzkumníka, který má přímý pedagogický vliv na respondenty - studenty. Studenti byli předem o výzkumu informováni a bylo jim sděleno, že se výzkumu nemusí účastnit. Získávaná demografická data neumožňovala konkrétní identifikaci studentů, s jednou výjimkou, kterou tvořili respondenti - studenti mužského pohlaví. Vzhledem k jejich počtu by byla identifikace pravděpodobně možná. Dle odpovědí na otevřené otázky, kam respondenti mohli vpisovat vlastní postřehy, je možno usoudit, že nelze tyto reakce posuzovat jako účelové. V odpovědích se objevují i negativní reakce či kritika: ... obsah některých predmětů je nevyvážen... malý počet neteologických C předmětů... některé zbytečné předměty.

I přes výše uvedené limity lze pokračovat ve formulování závěrů.

40 Uvedené výroky jsou výroky studentů studijního programu Sociální pedagogika. Byly zaznamenány na základě ústních rozhovorů se studenty v průběhu let 2009-2019. 


\section{Závěr}

Jedním z pilírư, na kterých stojí sociálně pedagogická praxe, je solidarita, tedy schopnost pomáhat těm, kteři to potřebují. Smékal ${ }^{41}$ uvádí, že podle Rejnvaldové mezi klíčové rysy osobnosti patří prosociální orientace, kterou lze charakterizovat jako dovednost vnímat tužby lidí, ochotu ke spolupráci, přání přinášet druhým radost a poskytovat jim pomoc. Solidarita a prosociální chování pak plně korespondují s křestanskými principy života, které lze vystihnout na základě dvou přikázání (Mk 12,30-31): ... miluj Hospodina, Boha svého, $z$ celého svého srdce, $z$ celé své duše, $z$ celé své mysli a z celé své sily! ... miluj svého bližního jako sám sebe! Druhé odkazuje na potřebu být zde i pro druhé. V souvislosti s tím Halík ${ }^{42}$ dodává, že náboženskost může být rozvinuta a pěstována, ... nebo zưstávat na okraji našeho života, zastíněna něčím jiným, nebo být úplně zanedbána, či dokonce vědomě potlačena. Jednou z možností rozvoje pak může být i studium Sociální pedagogiky, které by mělo vést, mimo jiné, $\mathrm{k}$ vnímání potřebnosti pomáhat druhým, $\mathrm{v}$ př́ípadě duchovního přesahu oboru pak $\mathrm{k}$ nezištné pomoci druhým, která je motivována samotným jedincem. Prezentovaný výzkum ukázal, že studenti subjektivně vnímají duchovní rozměr studia a že jej přijímají pozitivně, ale také to, že se toto vnímání zesiluje s dobou studia. Lze tedy konstatovat, že duchovní rozměr studijního oboru (v našem př́padě křestanská tradice) může být významným obohacením studijního programu Sociální pedagogika. V otevřených otázkách studenti mohli odpovídat, který z předmětů je pozitivně ovlivnil. Nejčastěji se objevovaly tyto předměty: religionistika, základy křestanství a křestan v současném světě, hodnoty a metodika zájmových činností - duchovní rozmèr.

V př́padě předmětu religionistika se studenti setkávají se základními charakteristikami hlavních světových náboženství. Předměty základy křestanství a křestan v současném světě mají stejný obsah, forma je však uzpůsobena tomu, zda se studenti hlásí či nehlásí ke křestanství. Základní téma těchto dvou předmětů je tajemství existence Boha a člověka. $V$ rámci předmětu hodnoty se pak studenti mají možnost zamýšlet nad problematikou hodnotové orientace dnešního člověka a nad možnostmi posilování pozitivních hodnot $\mathrm{v}$ současném světě. Praktický předmět metodika zájmové činnosti - duchovní rozměr ukazuje studentům, jak lze využít hru jako prostředek k předávání hodnot či jako prostor pro diskusi o hodnotách. Součástí semináře je také poukázání na duchovní dimenzi života člověka. Ríčan uvádí, že účast na zápasu mezi dobrem a zlem je pro mnohé těžištěm duchovního života. ${ }^{43}$

\section{Doporučení pro praxi}

Studium Sociální pedagogiky na CMTF UP má deklarovanou přidanou hodnotu v podobě duchovního rozměru, která by se měla projevovat ve dvou základních oblastech - obohacování předmětů o křestanský rozměr a působení príkladem akademických pracovníků. Na základě výpovědí studentů se jeví, že tuto přidanou hodnotu studenti poznávají a hodnotí ji spiše pozitivně. Pro další práci je vhodné pomocí kvalitativního paradigmatu popsat, jak vnímají studenti dopad duchovního rozměru studia na jejich pracovní život, tedy popsat, co si pod tím konkrétně představují, a tyto výpovědi porovnat s teoretickými východisky. Za výzvu lze považovat zaměření se na prohlubování osobnostního rozvoje studentů, především ve směru prosociálního chování

41 Srov. Vladimír SMÉKAL, Pozvání do psychologie osobnosti. Člověk v zrcadle vědomí a jednání, Brno: Společnost pro odbornou literaturu - Barrister \& Principal, 2009, s. 374.

42 HALÍK, Co je..., s. 28.

43 Pavel ŘÍČAN, Psychologie náboženství a spirituality, Praha: Portál, 2007, s. 109. 
a solidarity, což může mít žádoucí dopad na pojetí pracovního nastavení v oblasti sociálně-pedagogické praxe v duchu biblického výroku: starejte se jako pastýři o Boží stádce u vás, ne z donucení, ale dobrovolně, jak to Bůh žádá, ne z nízké zištnosti, ale s horlivou ochotou, ne jako páni nad těmi, kdo jsou vám svěreni (1P 5,2-3).

\section{Kontakt na autora}

doc. PhDr. \& Mgr. Petra Potměšilová, Ph.D.

Univerzita Palackého v Olomouci

Cyrilometodějská teologická fakulta, Katedra křest’anské výchovy

Univerzitní 244/22, 77111 Olomouc

petra.potmesilova@upol.cz 